\title{
Balkan Smoke: Tobacco and the Making of Modern Bulgaria.
}

By Mary C. Neuburger. Pp. 307. Ithaca: Cornell University Press. 2013. ISBN: 9780801450846.

Nationalism, class struggle, and geopolitics are some of the framing devices historians traditionally employ when writing general histories of modern nations. In her most recent book Mary Neuburger, Professor of History at the University of Texas at Austin, takes a rather different approach. She conducts an extensive examination of the last few centuries of Bulgarian history as viewed through the lens of a commercial commodity, and a very particular one at that - the tobacco leaf. In justifying her choice, Neuburger reminds us of the towering role tobacco has played in the history of modern Bulgaria. In 1918 tobacco made up almost 80\% of Bulgaria's export earnings, earning the moniker of 'Bulgarian gold'. By the late 1960s the country became the world's biggest exporter of cigarettes as the main supplier of the insatiable Soviet market. During the heyday of Communism as much as one-eighth of the Bulgarian population were involved in tobacco industry in some capacity. The author's claim that tobacco is inextricably tied to the fate of the Bulgarian nation is therefore strongly founded in its persisting economic importance.

Tobacco has been the maker and breaker of Bulgarian economy, but Balkan Smoke is not a work of economic history. Neuburger closely accounts for the political, but also cultural and social, importance of tobacco in Bulgaria and how its role had changed through time. The sources on which she bases her work, predominantly literary works and memoirs, reflect this bias. The narrative spans from the origins of the 'Bulgarian gold' in Ottoman Oriental leaf production to the collapse of the Bulgarian tobacco industry in the years after the disintegration of the Soviet Bloc. The bulk of the book, however, straddles the interwar period and the decades of the Communist rule in the country. The turning points are the two World Wars which saw hundreds of thousands of young men return home from the frontlines addicted to nicotine and ready to become faithful customers of the product that they were freely provided with as soldiers.

Neuburger is particularly good at highlighting the fascinating contradictions surrounding tobacco in Bulgarian history. One of them is the uneasy alliance of a portion of Bulgarian Socialists with the Protestant Church over the importance of temperance, both with regards to alcohol and smoking. Another one is the tangled economic relationship between the Jewish dominated-Bulgarian tobacco industry and the Nazis who, despite their ideological qualms, continued to import Bulgarian tobacco on a mass scale to Germany throughout the 1930s. Finally, Neuburger points out the inconsistent attitudes of the Bulgarian Communist leadership to smoking, who attempted to present it as a social deviance, while not compromising the economic benefits Bulgaria gained from the production and sale of tobacco, launching a number of sporadic and rather ineffective anti-smoking campaigns.

Perhaps inevitably for a work that traces the history of a single product, Neuburger occasionally seems to be overemphasising the centrality of tobacco in some of the key developments of modern Bulgarian history without considering alternative explanations. One example of this is her account of Bulgaria's descent into World War II on the side of Nazi Germany, where Neuburger makes the sweeping 
claim that 'tobacco trade brought potentially Allied countries like Bulgaria into the Axis fold' (p. 136) and is quick to sideline the strength of right-wing sentiments in the country. Throughout Balkan Smoke one wishes Neuburger would take more effort to step back and couch tobacco in the wider perspective of the complex historical dynamics of the region.

Despite these occasional setbacks, Balkan Smoke is an important piece of scholarship. In contrast to the significant literature on the history of tobacco in the USA or the Middle East, the role of tobacco in Eastern Europe has thus far been only sporadically tackled by English-language historians. This lack of interest is surprising especially considering the fact that it was in Eastern Europe that cigarette consumption in the 1980s and 1990s reached levels unprecedented anywhere else in the world. Excluding memoirs and non-scholarly books such as the one written by tobacco industry functionary Ivan Pitekov in 2010, Balkan Smoke is a pioneering work in the history of tobacco in Bulgaria, offering a much needed contribution to the historiography of the region.

MATEUSZ ZATOŃSKI

London School of Hygiene and Tropical Medicine

This work is licensed under the Creative Commons Attribution-Non-commercial-Share-alike 2.0 UK: England \& Wales License. This license allows for redistribution and alteration, commercial and non-commercial, as long as credit is given to the author. To view a full copy of this license, visit: http://creativecommons.org/licenses/ or send a letter to Creative Commons, 444 Castro Street, Suite 900, Mountain View. 